\title{
Monitoring and Evolution of Highly Lead Polluted Coastal Environments: A Case Study in San Simón Bay (NW Spain)
}

\author{
Álvarez-Iglesias P. ${ }^{1}$, Rodríguez-Germade I. ${ }^{1}$, Belén Rubio ${ }^{1}$, Rey D. ${ }^{1}$, Quintana B. ${ }^{2}$, Millos J. ${ }^{3}$ \\ ${ }^{1}$ Grupo GEOMA, Dpto. de Geociencias Marinas y Ordenación del Territorio, Facultad de Ciencias, Edificio de Ciencias Experimentales, \\ Universidade de Vigo, Vigo (Pontevedra) 36310 Spain \\ ${ }^{2}$ Laboratorio de Radiaciones Ionizantes, Dpto. de Física Fundamental, Universidad de Salamanca, Salamanca, 37008, Spain \\ ${ }^{3}$ Servicio de Seguridad Alimentaria y Desarrollo Sostenible, C.A.C.T.I., Universidade de Vigo, Vigo (Pontevedra) 36310, Spain
}

\begin{abstract}
San Simón Bay (inner Ría de Vigo, NW Spain) is a well-known polluted area because of its high $\mathrm{Pb}$ concentrations caused by waste discharges from a ceramic factory. The present study is focused on the historical and diagenetic monitoring of $\mathrm{Pb}$ pollution in this Bay based on sediment and pore water analyses of two cores collected in October 2010 adjacent to the factory using different techniques. A chronological framework was constructed based on ${ }^{137} \mathrm{Cs}$ and ${ }^{210} \mathrm{~Pb}$ dating. Lead stable isotope ratios confirmed that the ceramic factory is still the main $\mathrm{Pb}$ source despite its closing in 2001. The historical monitoring of $\mathrm{Pb}$ pollution included Itrax ${ }^{\mathrm{TM}}$ Core Scanner (Itrax) analyses on the sedimentary record and the comparison with previous geochemical studies. The location of $\mathrm{Pb}$ maxima values in the cores allowed the estimation of sedimentation rates which were similar to those calculated from radionuclide dating. Moreover, Itrax analyses supported the results of the other techniques, but providing results with a higher resolution, and providing information about variations in cores composition that could affect radionuclide activities. The short-time interval required for obtaining the Itrax results and the high-resolution of the data, among other applications of this scanner, confirmed its importance as a complementary tool for Environmental coastal management.
\end{abstract}

Publication History:

\section{Introduction}

Sediments from tidal flats and marshes can record the pollution coming from urban and industrial activities performed in the littoral. These ecosystems are usually quite protected from waves, while tidal currents are the main responsible of sediments' distribution creating a declining grain-size trend from the distal part (sandy sediments) to land (muddy sediments).The low hydrodynamic energy of these areas favours pollutants' accumulation in the sediments. For that reason, these fragile sedimentary environments are very sensitive to anthropogenic activities and they have been the target of numerous pollution studies [1-3].

The tidal flat of San Simón Bay (Ría de Vigo, NW Spain) is wellkown by its extremelly high pollution levels of $\mathrm{Pb}$, with concentrations between 500 and $65,400 \mu \mathrm{g} \mathrm{g}^{-1}$ [4]. This has been proved by many studies [4-14], where it is pointed to an ancient ceramic factory (Pontesa) located in the NE coast of the Bay as the main source of $\mathrm{Pb}$ pollution. Sediments of these area are characterized by high organic matter contents that fuel early diagenetic processes [4,7-8]. Despite the great knowledge on $\mathrm{Pb}$ pollution in San Simón Bay, this area has been selected for monitoring the historical and diagenetic evolution of $\mathrm{Pb}$ in the sedimentary record. In order to achieve this, one option is the use of geochronological methods, suh as those based in ${ }^{137} \mathrm{Cs}$ and ${ }^{210} \mathrm{~Pb}$, to construct a temporal framework $[15,16]$. The ${ }^{137} \mathrm{Cs}$ dating method is based on the identification of the maximum inputs of this artificial radionuclideto the environment [17,18]: 1986 (Chernobyl) and 1963 (the maximum of nuclear tests). The ${ }^{210} \mathrm{~Pb}$ dating method is based on the determination of the in excess ${ }^{210} \mathrm{~Pb}$ fraction $\left({ }^{210} \mathrm{~Pb}_{\mathrm{xs}}\right)$ and, afterwards, the adjustment of the activity profile by using an appropriate dating method [19-22]. Another option is to collect sediment cores in the same study area periodically, and then, analyze and compare them. If their analysis is made by conventional techniques this would imply a high number of samples, pretreatment and time-consumption (and cost) for getting results. Then, fast and non-destructive techniques, such as X-ray fluorescence (XRF) scanning with equipments like the Itrax ${ }^{\mathrm{xx}}$ Core Scanner (Itrax) would be preferred. This equipment requires very simple sample preparation (i.e. smoothing the core surface) and provide optical and radiographical images, and XRF data obtained in continuous mode at submillimetrical scale in a few hours [23]. Elements' contents are expressed as peak areas (the area integrals of the elements' characteristic peaks presented in each spectrum) that are proportional to element concentrations in the sediment. Despite the semi-quantitative nature of the Itrax data, several authors have demonstrated the ability of this kind of scanners to detect metal pollution in sediments, even at low concentrations [16,24-27]. However, we showthe utility of the Itrax for monitoring pollutionover time and as a complementary tool to support radionuclide analyses.

Pollution monitoring not only implies the following of pollution events over time but also the determination of their origin for identifying possible changes in sources. Sources of $\mathrm{Pb}$ pollution to the environment can be disentangled by analysing $\mathrm{Pb}$ stable isotope ratios, because each source of $\mathrm{Pb}$ (natural or anthropogenic) usually has a characteristic isotopic composition [10, 28-29]. Anthropogenic $\mathrm{Pb}$ inputs are usually less radiogenic than natural sources and their isotopic composition depends on the natural ores used in the different human activities.

"Corresponding Author: Dr. Belén Rubio, Grupo GEOMA, Dpto. de Geociencias Marinas y Ordenación del Territorio, Facultad de Ciencias, Edificio de Ciencias Experimentales, Universidade de Vigo, Vigo (Pontevedra) 36310 Spain; E-mail: brubio@uvigo.es

Citation: Álvarez-Iglesias P, Rodríguez-Germade I, Rubio B, Rey D, Quintana B (2016) Monitoring and Evolution of Highly Lead Polluted Coastal Environments: A Case Study in San Simón Bay (NW Spain). Int J Earth Environ Sci 1: 112. doi: http://dx.doi.org/10.15344/ijees/2016/112

Copyright: (C) 2016 Álvarez-Iglesias et al. This is an open-access article distributed under the terms of the Creative Commons Attribution License, which permits unrestricted use, distribution, and reproduction in any medium, provided the original author and source are credited. 
Citation: Álvarez-Iglesias P, Rodríguez-Germade I, Rubio B, Rey D, Quintana B (2016) Monitoring and Evolution of Highly Lead Polluted Coastal Environments: A Case Study in San Simón Bay (NW Spain). Int J Earth Environ Sci 1: 112. doi: http://dx.doi.org/10.15344/ijees/2016/112

Page 2 of 11

The main aim of this work is to follow the temporal evolution of the $\mathrm{Pb}$ records of San Simón Bay as well as the diagenetic processes that condition $\mathrm{Pb}$ bioavailability. To that end, a comprehensive analysis of sediments and pore waters have been made by applying different analytical techniques including the Itrax as a screening tool to improve the resolution of the results obtained in comparison to those obtained by conventional analyses. Moreover, the Itrax will be proven to be a fast option for sediment pollution monitoring, representing a quick tool for checking the compliance of regional environmental laws that should be integrated in the range of the techniques usually applied in environmental coastal management.

\section{Study Area}

The Ría de Vigo is the southernmost of the Galician Rías (NW Spain). It has a funnel morphology with an area of $176 \mathrm{~km}^{2}$ and an axial length of $33 \mathrm{~km}$. It is $10 \mathrm{~km}$ wide at its mouth and it gets narrower towards its head in the Rande Strait. Beyond this zone, the Ría widens again, forming the San Simón Bay which is smaller and shallower than the rest of the Ría. The San Simón Bay is $7.3 \mathrm{~km}$ long and $3.5 \mathrm{~km}$ wide, taking up an area of $19.5 \mathrm{~km}^{2}$. About one third of it is intertidal, under the influence of a mesotidal regime $(2$ to $4 \mathrm{~m}$ with an average of $2.2 \mathrm{~m}$ ) [30]. The main source of freshwater is the Oitavén-Verdugo River system $\left(13-17 \mathrm{~m}^{3} / \mathrm{s}\right)$, but little sediment has been deposited since the construction of the Eiras dam in 1977 [31] The San Simón Bay is an area of low hydrodynamic energy due to its orientation and morphology $[7,32]$ and its waters are thermally stratified during most of the year [13]. Sediments in the Bay result from a mixture of marine and terrestrial sources. They are rich in organic matter $(7-15 \%)$ and poor in carbonates $(<1 \%)[4]$. This bay shows a high productivity due to the intense upwelling processes which characterize the western margin of Iberia [33], and which have favored extensive marine cultures in the Galician Rías over the last one hundred years. Therefore, in this bay there are many rafts for mussel cultivation, and gatherers of shellfish collect by hand clams and cockles in the sand banks [7]. Despite the need of preserving the seabed quality, San Simón Bay receives polluting urban and industrial wastes from the sourrounding coastal towns and cities. An extremely severe enrichment by $\mathrm{Pb}$ was detected in the intertidal sediments of the bay $[4,6]$. The main $\mathrm{Pb}$ source was interpreted to be aceramic factory (Pontesa) $[6,10]$ located in the NE part of the Bay (near to the Oitavén-Verdugo system)(Figure1b), whose activity took place between 1972 and 2001

\section{Material and Methods}

This study is based on two cores collected in October 2010 at the same position close to the old ceramic factory $\left(42^{\circ} 20^{\prime} 48.83^{\prime \prime} \mathrm{N}\right.$; $8^{\circ} 36^{\prime} 50.88^{\prime \prime} \mathrm{W}$ ) in San Simón Bay (Figure 1b). One core was $26.5 \mathrm{~cm}$ long (core designation SS10T01) and its replica, $36 \mathrm{~cm}$ long (core designation SS10T03). This replica was intended for radionuclide analysis and water content determination, while the other analyses were performed on core SS10T01. Once in the laboratory cores were half-splitted and pore waters were collected by Rhizon ${ }^{\circ}$ samplers from core SS10T01. Then, it was extracted a $2 \mathrm{~cm}$ wide $\mathrm{U}$-channel from each core, and discrete samples were obtained each $1-\mathrm{cm}$. Analyses on core SS10T01 were made each 2-3 cm, while on core SS10T03, each $1 \mathrm{~cm}$.

Pore waters were divided in three aliquots, one for determining sulphates by Ultraviolet-Visible (UV-VIS) spectrometry in a Hewlett Packard HP 8452A (Limit of detection -LOD- $20 \mu \mathrm{g} \mathrm{L}^{-1}$ ); the second for determining sulphides by UV-VIS after adding $0.4 \mathrm{ml}$ of a solution of Zinc acetate $50 \mathrm{mM}$ per $\mathrm{ml}$; and the third, after acidification with $\mathrm{HNO}_{3}$ for determining $\mathrm{Pb}$, among other trace elements, by Inductively Coupled Plasma-Mass Spectrometry (ICP-MS) in a X Series ICP-MS Thermo Elemental (LOD $0.200 \mu \mathrm{g} \mathrm{L}^{-1}$ ).

Grain-size was determined in both cores by laser difraction particle size analysis with a Beckman Coulter Counter LS 13320 .

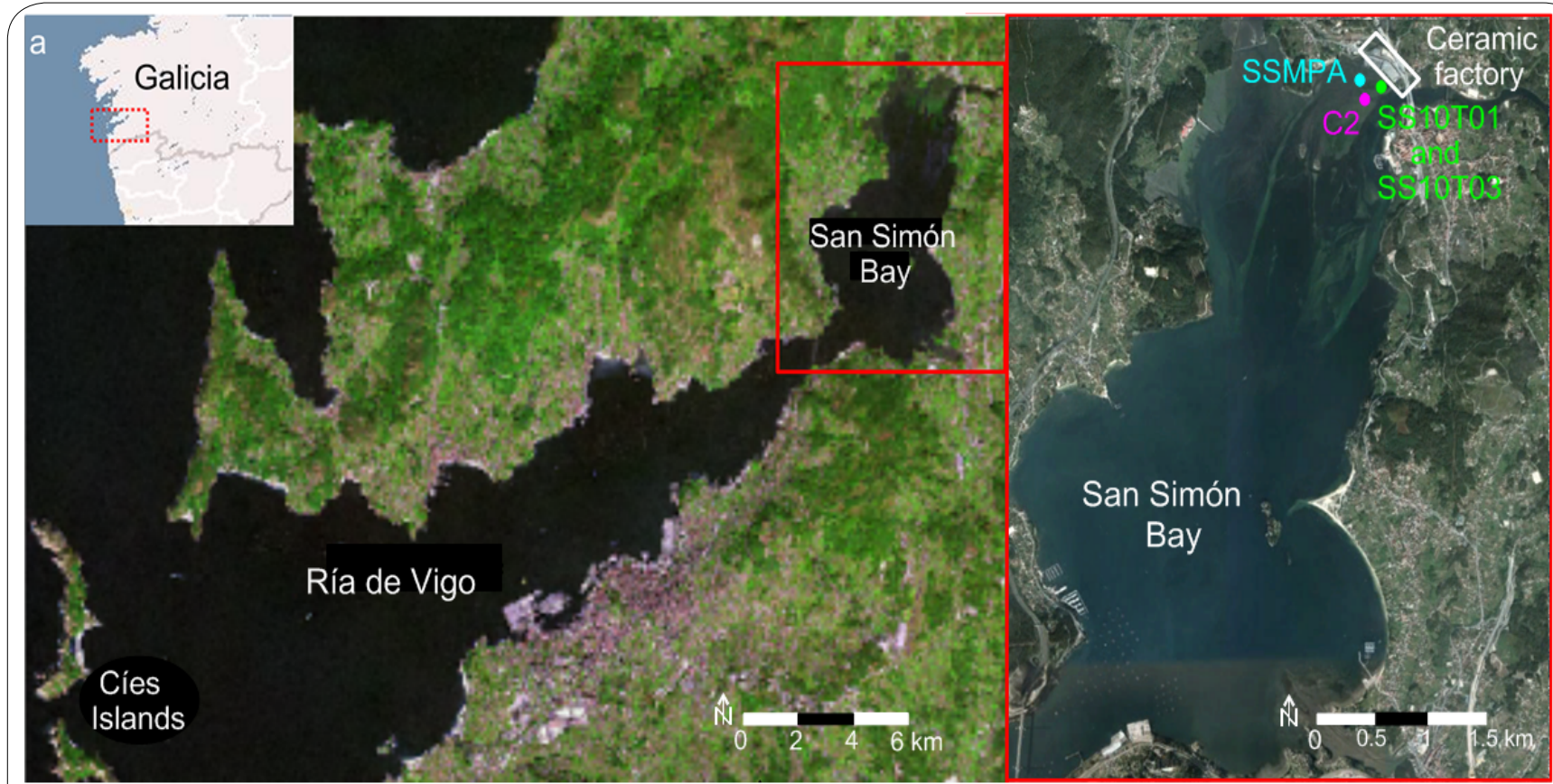

Figure 1: a) Map of the Ría de Vigo (NW Spain) showing the study area; b) Location of the SS10 cores (green dot) together with the SSMPA (blue dot) and the C2 (pink dot) cores at San Simón Bay. Cores SSMPA and C2 were collected in previous studies [8-9] and they were used for comparison. Note that these cores are close to Pontesa, the former ceramic factory (white rectangle). 
Citation: Álvarez-Iglesias P, Rodríguez-Germade I, Rubio B, Rey D, Quintana B (2016) Monitoring and Evolution of Highly Lead Polluted Coastal Environments: A Case Study in San Simón Bay (NW Spain). Int J Earth Environ Sci 1: 112. doi: http://dx.doi.org/10.15344/ijees/2016/112

Page 3 of 11

Percentages of total carbon (TC), total nitrogen (TN), total sulphur (TS) and total inorganic carbon (TIC) were determined with a LECO CNS-2000 analyzer in subsamples of core SS10T01. Total organic carbon (TOC) was estimated by subtracting the TIC from the TC, and carbonates percentage was calculated by multiplying the TIC by a stoichiometric factor of 8.33 .

The two extracted U-channels were analyzed with an Itrax ${ }^{\mathrm{TM}}$ Core Scanner (Itrax) using a Mo-tube, with a voltage of $30 \mathrm{kV}$ and a current of $55 \mathrm{~mA}$. The step size used was $500 \mu \mathrm{m}$ and the exposure time, 10 seconds. All results were re-evaluated using the Cox proprietary software Q-Spec 6.5.2.

Total concentrations of $\mathrm{As}, \mathrm{Ba}, \mathrm{Co}, \mathrm{Cr}, \mathrm{Cu}, \mathrm{Mn}, \mathrm{Ni}, \mathrm{Pb}, \mathrm{Sr}, \mathrm{V}$ and $\mathrm{Zn}$ in sediments (core SS10T01) were also obtained from conventional XRF analysis by using a fluorescence spectrometer SIEMENS SRS 3000 .

The methods proposed by the National Water Research Institute (Canada) for trace elements [34] were followed to obtain the bioavailable $\mathrm{Pb}$ fraction, the recoverable $\mathrm{Pb}$ fraction and the total $\mathrm{Pb}$ content in sediments. In such away, three replicas for each subsample were procesed using $\mathrm{HCl}$, a mixture of $\mathrm{HCl}, \mathrm{HNO}_{3}$ and $\mathrm{H}_{2} \mathrm{O}_{2}$, and the former mixture plus HF, respectively. Lead content in the digests, as well as the total contents of several trace elements $(\mathrm{Ag}, \mathrm{Cr}, \mathrm{Cu}$ and $\mathrm{Zn}$, among others) were determined by Inductively Coupled Plasma Optical Emission Spectrophotometry (ICP-OES) using a Perking Elmer Optima 4300DV. Certified reference materials MESS-3 and PACS-2 (NRC, Canada) were analyzed to check for accuracy and precision of total $\mathrm{Pb}$ content determination and total recoveries were obtained (Table 1).

\begin{tabular}{|l|l|l|l|}
\hline CRM & $\begin{array}{l}\text { Certified value } \\
\left(\mu \mathrm{g} \mathrm{g}^{-1}\right)\end{array}$ & $\begin{array}{l}\text { Measured value } \\
\left(\mu \mathrm{g} \mathrm{g}^{-1}\right)\end{array}$ & $\mathrm{N}$ \\
\hline MESS-3 & $21.1 \pm 0.7$ & $25.4 \pm 6.9$ & 5 \\
\hline PACS-2 & $191.0 \pm 17.0$ & $192.8 \pm 5.3$ & 5 \\
\hline
\end{tabular}

Table 1: Comparison of the $\mathrm{Pb}$ analytical results of the analysed certified reference materials (CRM), MESS-3 and PACS-2

Lead stable isotope ratios $\left({ }^{206} \mathrm{~Pb} /{ }^{204} \mathrm{~Pb},{ }^{207} \mathrm{~Pb} /{ }^{204} \mathrm{~Pb},{ }^{208} \mathrm{~Pb} /{ }^{204} \mathrm{~Pb}\right.$, ${ }^{208} \mathrm{~Pb} /{ }^{206} \mathrm{~Pb}$ and ${ }^{207} \mathrm{~Pb} /{ }^{206} \mathrm{~Pb}$ ) were determined in the samples obtained from the different extracts (bioavailable, recoverable and total) by Inductively Coupled Plasma Multi-collector Mass Spectrometry (ICP-MC-MS) using a Thermo-Finnigan Neptune. Selected samples were analyzed after preconcentration using a cation exchange resin (TrisKem International, France) in order to check if there were matrix interferences. Differences in isotopic ratios determination between digested samples and samples preconcentrated after digestion were minimal (on average 0.005\%). NIST SRM-997 Tl was used as a spike for mass bias correction. NIST SRM 981 was used to check for isotope relationships accuracy, calibration and isotope correction factors. Precision for ${ }^{207} \mathrm{~Pb} /{ }^{206} \mathrm{~Pb}$ was around $0.01 \%$ and for ${ }^{204} \mathrm{~Pb} /{ }^{206} \mathrm{~Pb}$ and ${ }^{208} \mathrm{~Pb} /{ }^{206} \mathrm{~Pb}$ ratios around $0.02 \%$ on the basis of two standard deviations $(2 \sigma)$.

Different mixture models were applied to the $\mathrm{Pb}$ isotopic ratios for obtaining the total anthropogenic component - TAC-[35], the $\mathrm{Pb}$ isotopic signature of the anthropogenic inputs for each depth $[35,36]$ and the apportionment of the $\mathrm{Pb}$ anthropogenic sources (considering three possible sources) $[37,38]$. Details of these models can be checked in Álvarez-Iglesias et al. [10].
Thirty-five sources were counted in an n-type coaxial low-level background HPGe detector (CANBERRA). For details on source preparation, spiking, equipment background and spectra analyses see Álvarez-Iglesias et al. [8]. The specific activities of ${ }^{210} \mathrm{~Pb},{ }^{214} \mathrm{~Pb}$, ${ }^{226} \mathrm{Ra},{ }^{137} \mathrm{Cs},{ }^{234} \mathrm{Th},{ }^{235} \mathrm{U}$ and ${ }^{40} \mathrm{~K}$ were determined. Water content was determined in the same samples by weight-loss after drying the samples at $50^{\circ} \mathrm{C}$ up to constant weight, considering the ratio water/ humid sediment.

All the analytical work was performed at the Central Research Services of the University of Vigo (C.A.C.T.I.) excepting radionuclide analyses, which were performed at the Ionizing Radiation Laboratory of the University of Salamanca.

\section{Results}

\section{SS10T01 core}

SS10T01 sediments were mostly sandy silts, although some levels of silty sands (at depths of 2 and $7 \mathrm{~cm}$ ) were observed (Figure 2). Furthermore, significant contents of coarse sands were detected at 7 , 23 and $25 \mathrm{~cm}$.

TOC, TN and TS contents decreased downwards, being their profiles very similar. TOC values ranged between 1.06 and 3.14\%; TN between non-detectable contents $(\mathrm{LOD}=0.4 \%)$ and $0.27 \%$, and TS between non-detectable contents $(\mathrm{LOD}=0.15 \%)$ and $0.39 \%$ (Figure 2). Carbonates were only detected at $17-20 \mathrm{~cm}(0.10 \%$; LOD $=0.05 \%)$.

Two distinct facies can be defined for the SS10T01 core (Figure 2). Facies 1 comprises the dark-coloured uppermost $13.5 \mathrm{~cm}$, showing TOC and TS contents larger than $1.5 \%$ and $0.2 \%$ respectively, and little or none $\mathrm{CaCO}_{3}$. Facies 2 comprises the light-coloured underlying part of the core showing lower TOC and TS contents than facies 1 , and a higher $\mathrm{CaCO}_{3}$ content $(>0.5 \%)$.

Sulphate contents in pore-waters decreased with depth (from 613 to $58 \mathrm{mg} \mathrm{L}^{-1}$, Figure 2), while sulphide contents were low (up to $250 \mu \mathrm{g}$ $\left.\mathrm{L}^{-1}\right)$, being non-detectable at 14 and $18 \mathrm{~cm}\left(\mathrm{LOD}=20 \mu \mathrm{g} \mathrm{L}^{-1}\right)$. Lead was not detected in the pore-water aliquots $\left(\mathrm{LOD}=0.200 \mu \mathrm{g} \mathrm{L}^{-1}\right)$.

Total $\mathrm{Pb}$ contents in sediments were extremely high $(17,200-66,700$

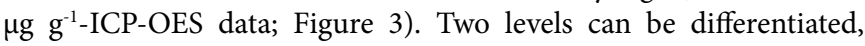
an upper level up to $13 \mathrm{~cm}$ with a higher $\mathrm{Pb}$ content $(4.92 \pm 1.40 \%)$, and a lower level from $13 \mathrm{~cm}$ to the bottom of the core, with a lower $\mathrm{Pb}$ content $(2.09 \pm 0.47 \%)$. The $\mathrm{Pb}$ content variability throughout the sedimentary record can be clearly observed from the $\mathrm{Pb}$ Itrax results (20,278-93,435 peak area; Figure 3). A noticeable subsurficial maximum was detected between 7 and $13 \mathrm{~cm}$, with $\mathrm{Pb}$ contents higher than $5.2 \%$. At this depth interval, it was also detected relatively high contents of $\mathrm{Ag}$, As, $\mathrm{Cr}$, Cu and $\mathrm{Zn}$ (Figure 3). Furthermore, high contents of $\mathrm{Cu}$ and $\mathrm{Zn}$ were detected at deeper levels (at $18 \mathrm{~cm}$ for $\mathrm{Cu}$ and at 16 and $24 \mathrm{~cm}$ for $\mathrm{Zn}$ ).

The $\mathrm{Pb}$ profiles in the bioavailable and the recoverable fractions were similar to that of the total $\mathrm{Pb}$ content, although with lower concentrations $(0.29-1.08 \%$ in the bioavailable fraction, and 0.83 $4.12 \%$ in the recoverable fraction; Figure 4 ). The bioavailable fraction represented around $18 \%$ of total $\mathrm{Pb}$ and its contribution increased, in general, with depth, whereas the recoverable fraction constituted around $56 \%$ of total $\mathrm{Pb}$ and its contribution was maxima between 5 and $13 \mathrm{~cm}$ 
Citation: Álvarez-Iglesias P, Rodríguez-Germade I, Rubio B, Rey D, Quintana B (2016) Monitoring and Evolution of Highly Lead Polluted Coastal Environments: A Case Study in San Simón Bay (NW Spain). Int J Earth Environ Sci 1: 112. doi: http://dx.doi.org/10.15344/ijees/2016/112

Page 4 of 11
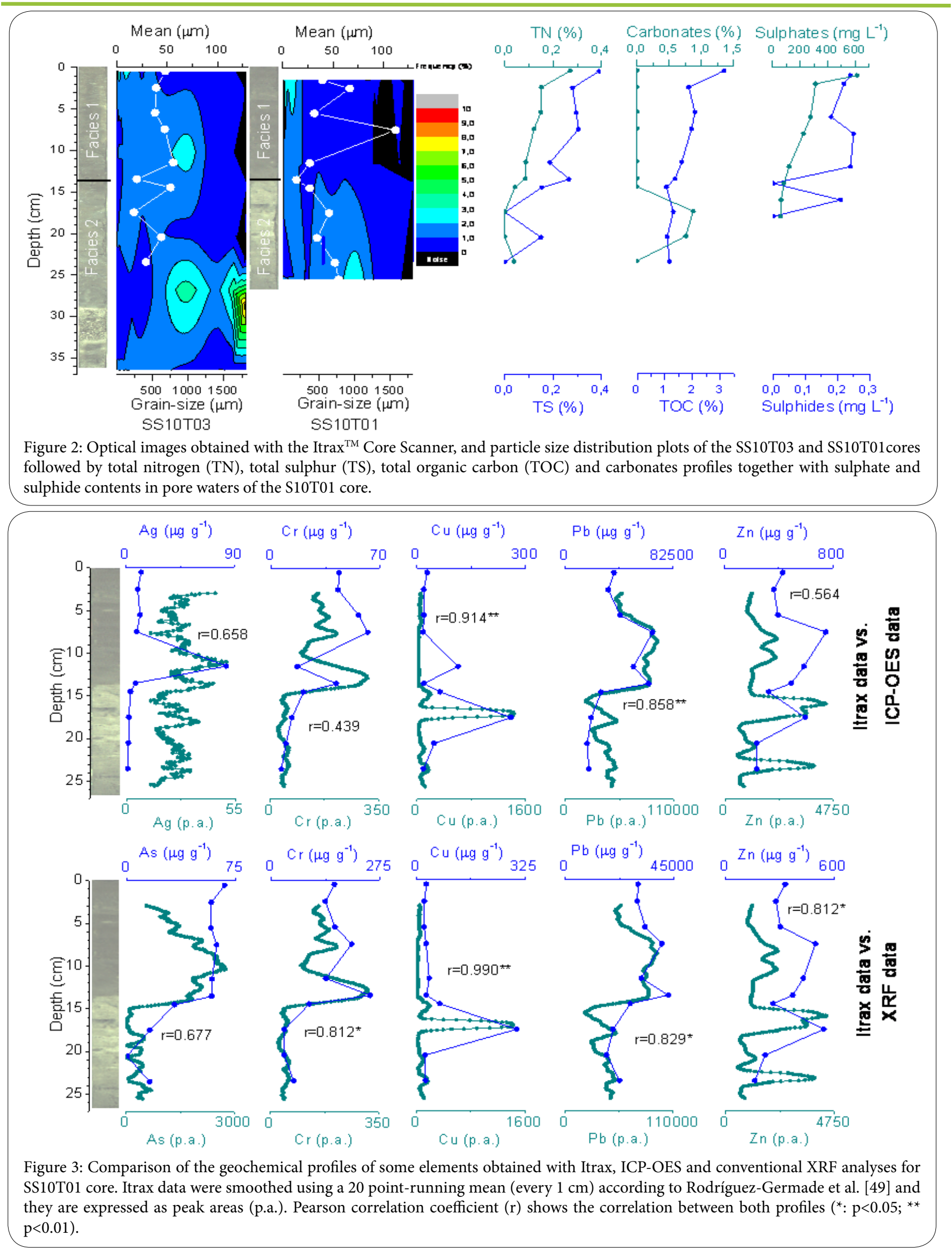

Int J Earth Environ Sci

IJEES, an open access journal Volume 1. 2016. 112 
Citation: Álvarez-Iglesias P, Rodríguez-Germade I, Rubio B, Rey D, Quintana B (2016) Monitoring and Evolution of Highly Lead Polluted Coastal Environments: A Case Study in San Simón Bay (NW Spain). Int J Earth Environ Sci 1: 112. doi: http://dx.doi.org/10.15344/ijees/2016/112

Page 5 of 11

The ${ }^{206} \mathrm{~Pb} /{ }^{207} \mathrm{~Pb},{ }^{206} \mathrm{~Pb} /{ }^{204} \mathrm{~Pb},{ }^{207} \mathrm{~Pb} /{ }^{204} \mathrm{~Pb},{ }^{208} \mathrm{~Pb} /{ }^{204} \mathrm{~Pb}$ and ${ }^{208} \mathrm{~Pb} /{ }^{207} \mathrm{~Pb}$ ratios profiles for the bioavailable and recoverable fractions and for the bulk samples of the SS10T01 core, were similar (Figure 4), with a marked minima at $11 \mathrm{~cm}$. The individual $\mathrm{Pb}$ isotopic ratios were also similar between the different fractions (Table 2); with slightly lower ratios in the recoverable fraction, and slightly higher ratios, in general, in the total fraction. For example, the ${ }^{206} \mathrm{~Pb} /{ }^{207} \mathrm{~Pb}$ ratios were $1.1627 \pm 0.0048$ in the bioavailable fraction, $1.1615 \pm 0.0048$ in the recoverable fraction, and $1.1632 \pm 0.0050$ in the total fraction (Figure 4). Subsamples collected at the same depth showed very similar individual $\mathrm{Pb}$ isotopic ratios among the different fractions, excepting the deepest samples (from $17 \mathrm{~cm}$ ). lower level from $16.5 \mathrm{~cm}$ up to the bottom of the core with a lower $\mathrm{Pb}$ content $(43,530 \pm 19,860$ p.a.). A big subsurficial $\mathrm{Pb}$ maximum was detected between 11 and $13 \mathrm{~cm}$, with an average peak area of 88,100.

Fe and Ti Itrax profiles for the SS10T03 core were very similar (Figure 5): Fe and Ti contents decreased from surficial sediments ( 400-700 p.a. for Ti and $\sim 15,000-20,000$ p.a. for $\mathrm{Fe}$ ) up to around $10 \mathrm{~cm}$ ( 400 p.a. for Ti and $\sim 11,500$ p.a. for Fe); then their contents slightly increased downwards (with contents in the same range as the upper sediments), excepting a marked maximum at around $31 \mathrm{~cm}$ ( 700 p.a. for $\mathrm{Ti}$ and $\sim 20,000$ p.a. for $\mathrm{Fe})$.
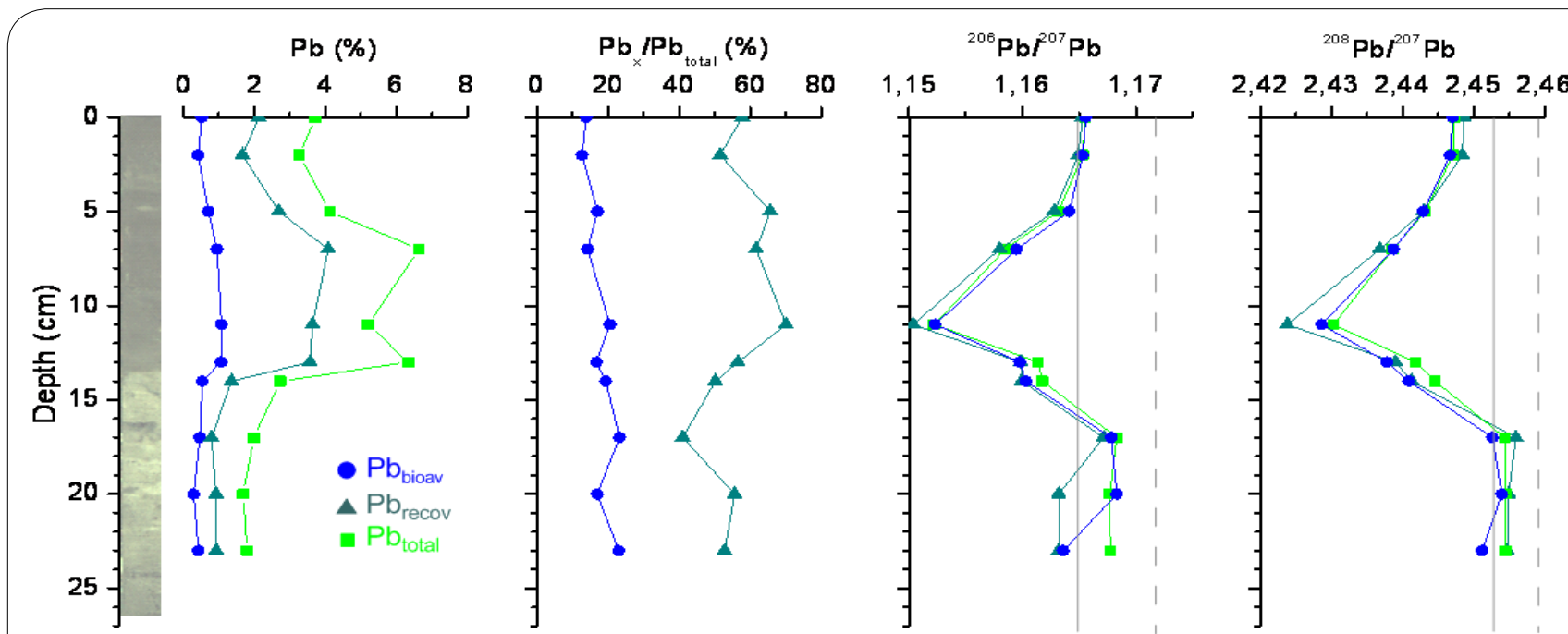

Figure 4: Lead content in the bioavailable $\left(\mathrm{Pb}_{\text {bioav }}\right)$ and the recoverable $\left(\mathrm{Pb}_{\text {recov }}\right)$ fractions compared to total content (by ICP-MS), their relative percentage; and their ${ }^{206} \mathrm{~Pb} /{ }^{207} \mathrm{~Pb}$ and ${ }^{208} \mathrm{~Pb} /{ }^{207} \mathrm{~Pb}$ ratios for $\mathrm{SS} 10 \mathrm{~T} 01$ core. The ${ }^{206} \mathrm{~Pb} /{ }^{207} \mathrm{~Pb}$ and ${ }^{208} \mathrm{~Pb} /{ }^{207} \mathrm{~Pb}$ characteristic of ceramic factory samples $\mathrm{P} 3$ (continuous line) and $\mathrm{P} 4$ (dashed line) are shown for allowing comparison [10].

\begin{tabular}{|l|l|l|l|l|l|l|}
\hline Sediment fraction & ${ }^{206} \mathrm{~Pb} /{ }^{207} \mathrm{~Pb}$ & ${ }^{208} \mathrm{~Pb} /{ }^{207} \mathrm{~Pb}$ & ${ }^{206} \mathrm{~Pb} /{ }^{204} \mathrm{~Pb}$ & ${ }^{207} \mathrm{~Pb} /{ }^{204} \mathrm{~Pb}$ & ${ }^{208} \mathrm{~Pb} /{ }^{204} \mathrm{~Pb}$ \\
\hline Bioavailable & 1.1483 & 2.4227 & 17.894 & 15.581 & 37.756 \\
\hline Recoverable & 1.1476 & 2.4276 & 17.890 & 15.585 & 37.843 \\
\hline Total & 1.1495 & 2.4270 & 17.919 & 15.587 & 37.831 \\
\hline SSMPA & 1.1657 & 2.4496 & 18.194 & 15.617 & 38.255 \\
\hline P3 & 1.1649 & 2.4524 & 18.171 & 15.599 & $38.256-0.7325$ \\
\hline P4 & 1.1796 & 2.4591 & 18.323 & 15.635 & $38.647-0.7377$ \\
\hline
\end{tabular}

Table 2: $\mathrm{Pb}$ stable isotope ratios for the total anthropogenic component (TAC) according to the mixture model proposed by Ferrand et al. [35] for the different fractions studied in core SS10T01 $(\mathrm{N}=10)$. TAC values for an intertidal core (SSPMA) recovered in the study are also shown for allowing comparison [10]. Isotopic ratios for natural sediments typical of the granitic watershed of the San Simón Bay and for a gypsum (P3) and a ceramic glaze (P4) samples collected in the waste channel of the ceramic factory located in the study area are also indicated [4].

\section{SS10T03 core}

Sediments of the SS10T03 core were mostly sandy silts, although some levels of coarse sands and silty sands were observed at the bottom of the core (at 32 and $36 \mathrm{~cm}$, respectively). Some levels showed a significant content of coarse sands (at 11,14 and $32 \mathrm{~cm}$ ). Facies distribution was the same as in the SS10T01 core (Figure 2) but with an additional layer of coarse sands near the bottom.

Lead contents were in the range of those detected in the SS10T01 core $(56,500 \pm 21,200$ average peak area (p.a.) in front of $57,950 \pm 22,320$ p.a.; Figures 3 and 5). Two levels can be differentiated, an upper level up to $16.5 \mathrm{~cm}$ with a higher $\mathrm{Pb}$ content $(70,770 \pm 11,030$ p.a. $)$, and a
Water content decreased in general from surface $(34 \%)$ to $30 \mathrm{~cm}$ $(15 \%)$, with a small maximum at $27 \mathrm{~cm}(33 \%)$, and then, it increased towards the bottom (where it was about $46 \%$; Figure 5). Its profile was similar in the upper $13 \mathrm{~cm}$ to those of $\mathrm{Fe}$ and Ti. Previous studies on San Simón Bay sediments [8] showed that water, TOC, $\mathrm{Al}$ and $\mathrm{Fe}$ profiles were similar among them and that they can be considered as grain size proxies.

Specific activity radionuclides profiles of SS10T03 core showed clearly that grain size influence (Figure 5). ${ }^{214} \mathrm{~Pb},{ }^{234} \mathrm{Th},{ }^{235} \mathrm{U}$ and ${ }^{40} \mathrm{~K}$ profiles were very similar to those of $\mathrm{Fe}, \mathrm{Ti}$ and water content. The deepest samples of the core showed a marked increase in the specific activities of ${ }^{210} \mathrm{~Pb},{ }^{214} \mathrm{~Pb},{ }^{234} \mathrm{Th},{ }^{235} \mathrm{U}$, and ${ }^{40} \mathrm{~K}$, probably related to 


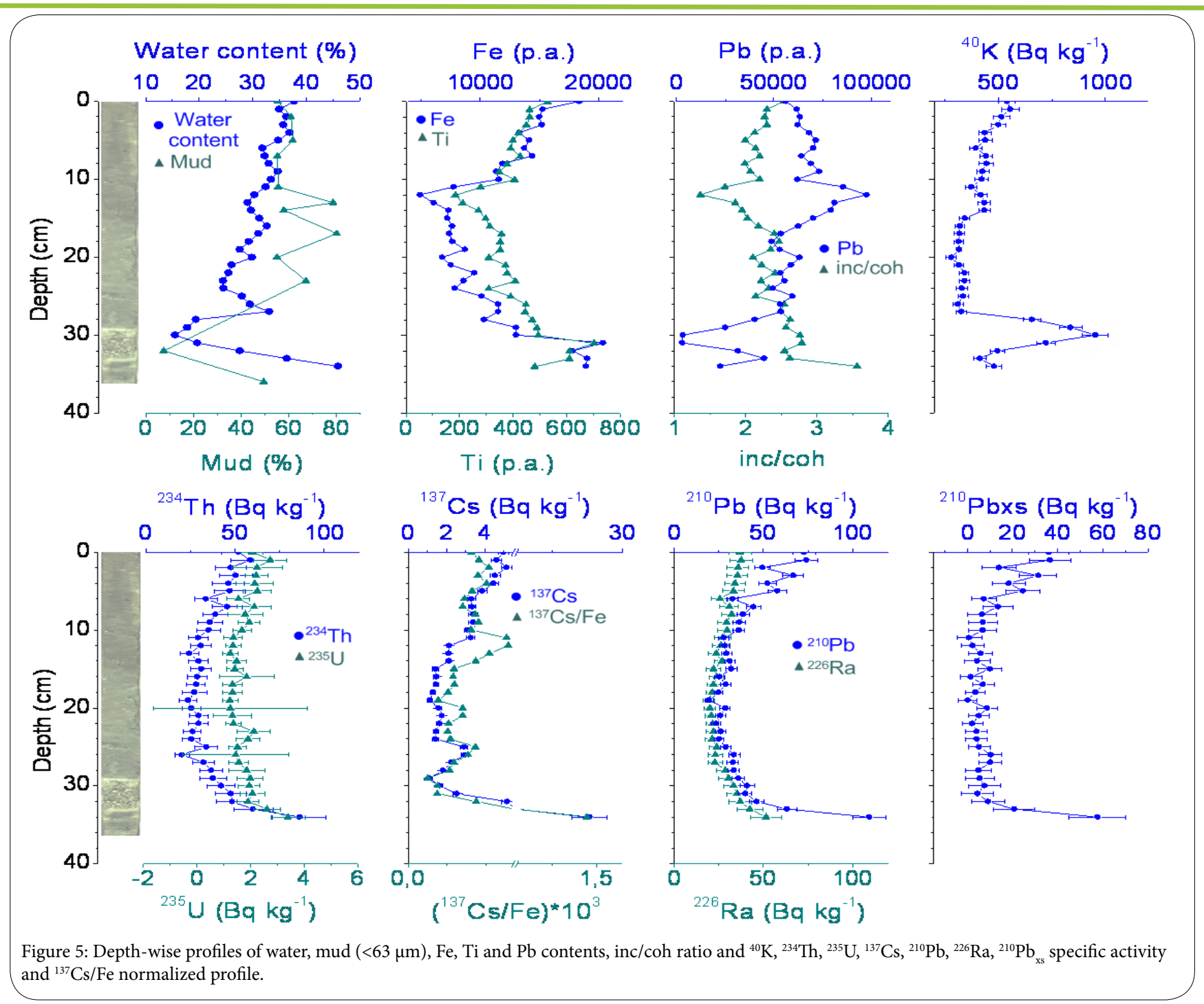

higher contents of organic matter and fine-grained sediments in these samples. The deepest sample of the core showed a very high ${ }^{137}$ Cs specific activity. Then, trying to minimize grain size influence, the ${ }^{210} \mathrm{~Pb}_{\mathrm{xs}}$ and ${ }^{137} \mathrm{Cs}$ profiles were normalized by the Fe content. The normalization did not modify the observed ${ }^{210} \mathrm{~Pb}_{\mathrm{xs}}$ profile, but it decreased the variability observed in the ${ }^{137} \mathrm{Cs}$ profile, excepting for the deepest samples.

The specific activity of ${ }^{137} \mathrm{Cs}$ varied between 1.08 and $27.66 \mathrm{~Bq} \mathrm{~kg}^{-1}$ and showed relative maxima at $26 \mathrm{~cm}$ and at the bottom of the core $(34 \mathrm{~cm})$, while $\mathrm{Fe}$-normalized profile showed relative maxima at 12 $\mathrm{cm}, 25 \mathrm{~cm}$ and at the bottom. Taking into account the high contents of water, $\mathrm{Fe}$ and $\mathrm{Ti}$ at the bottom, the ${ }^{137} \mathrm{Cs}$ maxima observed at this level is considered to be due to a matrix effect and is not going to be considered as a time-marker. Then, assigning the years 1987 and 1963 to the other maxima observed in the Fe-normalized ${ }^{137} \mathrm{Cs}$ specific activity profile at $12 \mathrm{~cm}$ and $25 \mathrm{~cm}$, respectively, sedimentation rates of 5.2 and $5.4 \mathrm{~mm} \mathrm{yr}^{-1}$ could be obtained. When the year 1963 was assigned to the maxima observed at $26 \mathrm{~cm}$ in the ${ }^{137} \mathrm{Cs}$ specific activity profile, sedimentation rates of $5.5 \mathrm{~mm} \mathrm{yr}^{-1}$ were obtained.

The specific activities of ${ }^{226} \mathrm{Ra}$ varied from $19.52(3.39)$ to $51.57(8.62)$ $\mathrm{Bq} \mathrm{kg}^{-1}$, while for total ${ }^{210} \mathrm{~Pb}$, from $19.58(2.24)$ to $109.33(9.22)$
$\mathrm{Bq} \mathrm{kg}{ }^{-1} .{ }^{210} \mathrm{~Pb}_{\mathrm{xs}}$ was detected throughout the core (although several samples showed values close to zero activity), with a marked maximum at the bottom, related to the sediment matrix. The ${ }^{210} \mathrm{~Pb}_{\mathrm{xs}}$ activity was estimated by subtraction of the ${ }^{226} \mathrm{Ra}\left(\right.$ from ${ }^{214} \mathrm{~Pb}$ ) activity from that of ${ }^{210} \mathrm{~Pb}$ for each sample. The ${ }^{210} \mathrm{~Pb}_{\mathrm{xs}}$ specific activity profile showed an almost monotonic decrease with depth in the first $10 \mathrm{~cm}$, from activity values of 35.92(8.93) to $6.59(6.23) \mathrm{Bq} \mathrm{kg}^{-1}$. Two dating models were applied, the CF: CS model (for details on the model see [21] and the CRS-MV model [41]. The CF: CS model was applied (considering constant sedimentation rates and negligible mixing) to the upper $10 \mathrm{~cm}$ of the core. In this core section, ${ }^{226} \mathrm{Ra}$ specific activity values were nearly constant $\left(32.79 \pm 3.65 \mathrm{~Bq} \mathrm{~kg}^{-1}\right)$, while below this section, activities were slightly lower (around $23 \mathrm{~Bq} \mathrm{~kg}^{-1}$ ) up to $28 \mathrm{~cm}$, and then increased markedly (up to $51.57 \mathrm{~Bq} \mathrm{~kg}^{-1}$ ). Mean sedimentation rates were obtained by a weighted least-squares fitting procedure [42] from the ${ }^{210} \mathrm{~Pb}_{\mathrm{xs}}$ specific activity profile plotted on a log scale against both depth and mass depth, which resulted in a linear profile for the considered section (Figure 6a). Then, apparent sedimentation rates of $2 \mathrm{~mm} \mathrm{yr}^{-1}$ and mass accumulation rates of $4.5 \mathrm{~g} \mathrm{~cm}^{-2} \mathrm{yr}^{-1}$ were obtained. Nevertheless, when applying the CRS-MV model that keeps track for compaction, considering only a constant ${ }^{210} \mathrm{~Pb}_{\mathrm{xs}}$ flux to the sediment, where the sediment accumulation rates are estimated from the 
Citation: Álvarez-Iglesias P, Rodríguez-Germade I, Rubio B, Rey D, Quintana B (2016) Monitoring and Evolution of Highly Lead Polluted Coastal Environments: A Case Study in San Simón Bay (NW Spain). Int J Earth Environ Sci 1: 112. doi: http://dx.doi.org/10.15344/ijees/2016/112

Page 7 of 11

minimum variance of the least-squares fit of the line representing the ${ }^{210} \mathrm{~Pb}_{\mathrm{xs}}$ inventory (considering measuring uncertainties), average sedimentation rates of $7.6 \pm 4.0 \mathrm{~mm} \mathrm{yr}^{-1}$ and average mass accumulation rates of $2.10 \pm 1.10 \mathrm{~g} \mathrm{~cm}^{-2} \mathrm{yr}^{-1}$ were obtained (Figure 6b). The total ${ }^{210} \mathrm{~Pb}_{\mathrm{xs}}$ inventory was $9,710 \pm 1,050 \mathrm{~Bq} \mathrm{~m}^{-2}$ and the corresponding ${ }^{210} \mathrm{~Pb}_{\mathrm{xs}}$ flux, $300 \pm 30 \mathrm{~Bq} \mathrm{~m}^{-2} \mathrm{yr}^{-1}$.

\section{Discussion}

\section{Geochemical interpretation of the cores}

The marked decrease in the TOC and TN profiles and in the sulphate pore water contents observed in the upper part of the SS10T01 core (Figure 2) suggests that the oxic zone spans the first $2.5 \mathrm{~cm}$. This limit coincides with those defined by Álvarez-Iglesias and Rubio [43] because the high organic matter content in San Simón sediments makes the oxic zone to be restricted to a few upper centimeters. TOC, TN and sulphate contents continued to decrease in the suboxic zone of the studied sediments (Figure 2). The sulphide content in porewaters is very low due to the oxidation of sulphides both in the oxic and the suboxic zones (Figure 2).

Itrax data allow obtaining geochemical variations with highresolution directly from sediment cores in a few hours. Figure 3 shows the comparison of some elements profiles of the SS10T01 core obtained with the Itrax versus those got by ICP-OES and conventional XRF analyses. The Itrax profiles show basically the same features than those obtained from the ICP-OES and XRF analyses on discrete samples with a slight depth offset in some cases. Features mismatches are due to a combination of discrete sampling constraints and differences in relative resolution depths. The correlation range obtained between the Itrax profiles and conventional techniques (reaching an $r=0.858$; $\mathrm{p}<0.01$, in the case of correlation with the $\mathrm{Pb}$ obtained from ICP-OES analyses) proved the reliability of the Itrax data to rapidly know the relative variations of sediment composition along the cores.

Following the relative variations in the $\mathrm{Pb}$ content in the two SS10 cores, Figures 3 and 5 showed some differences in spite of that both cores are replicates. However, similarities can be clearly detected in both $\mathrm{Pb}$ profiles. Lead maximum in the SS10T03 core (around 98,000 p.a.) matches with the $\mathrm{Pb}$ peak in the SS10T01 core around 85,000 p.a.) at $13 \mathrm{~cm}$. Below this depth, there is a significant peak area decrease downwards in both cases, more marked in the SS10T01 core. Thickness differences between the $\mathrm{Pb}$ peaks in cores SS10T01 and SS10T03 resulted from the tail inhomogeneity and subsequent modification of the local sedimentation conditions at the sampling site scale.

Itrax data are also useful for searching the origin of metal pollution from relationships between different elements. A significant correlation was obtained between $\mathrm{Pb}$ and $\mathrm{Zn}(\mathrm{r}=0.64, \mathrm{p}<0.05)$ because $\mathrm{Zn}$ oxide is widely used in the ceramic industry. High contents of $\mathrm{Zn}$ were previously indicated for waste channel samples from the ceramic factory (up to $0.09 \%$ ) [4]. Moreover, some of the ceramic pieces made in this factory were decorated with Ag-thread; therefore, Ag pollution could come from this industry too, in spite of its lower correlation with $\mathrm{Pb}(\mathrm{r}=0.46, \mathrm{p}>0.05)$. The lack of a good correlation in this case could be due to a temporary use of Ag in Pontesa. On the other hand, the best correlation was found between $\mathrm{Pb}$ and $\mathrm{As}(\mathrm{r}=0.93, \mathrm{p}<0.01)$, suggesting that As could be used as a glaze in the old ceramic factory, as it was proposed by Howarth et al. [13]. Furthermore, the high concentration of these elements in the uppermost $13.5 \mathrm{~cm}$ (Figure 3) where the TOC content is higher (Figure 2) suggests that the organic matter could be a ligand for these trace metals.

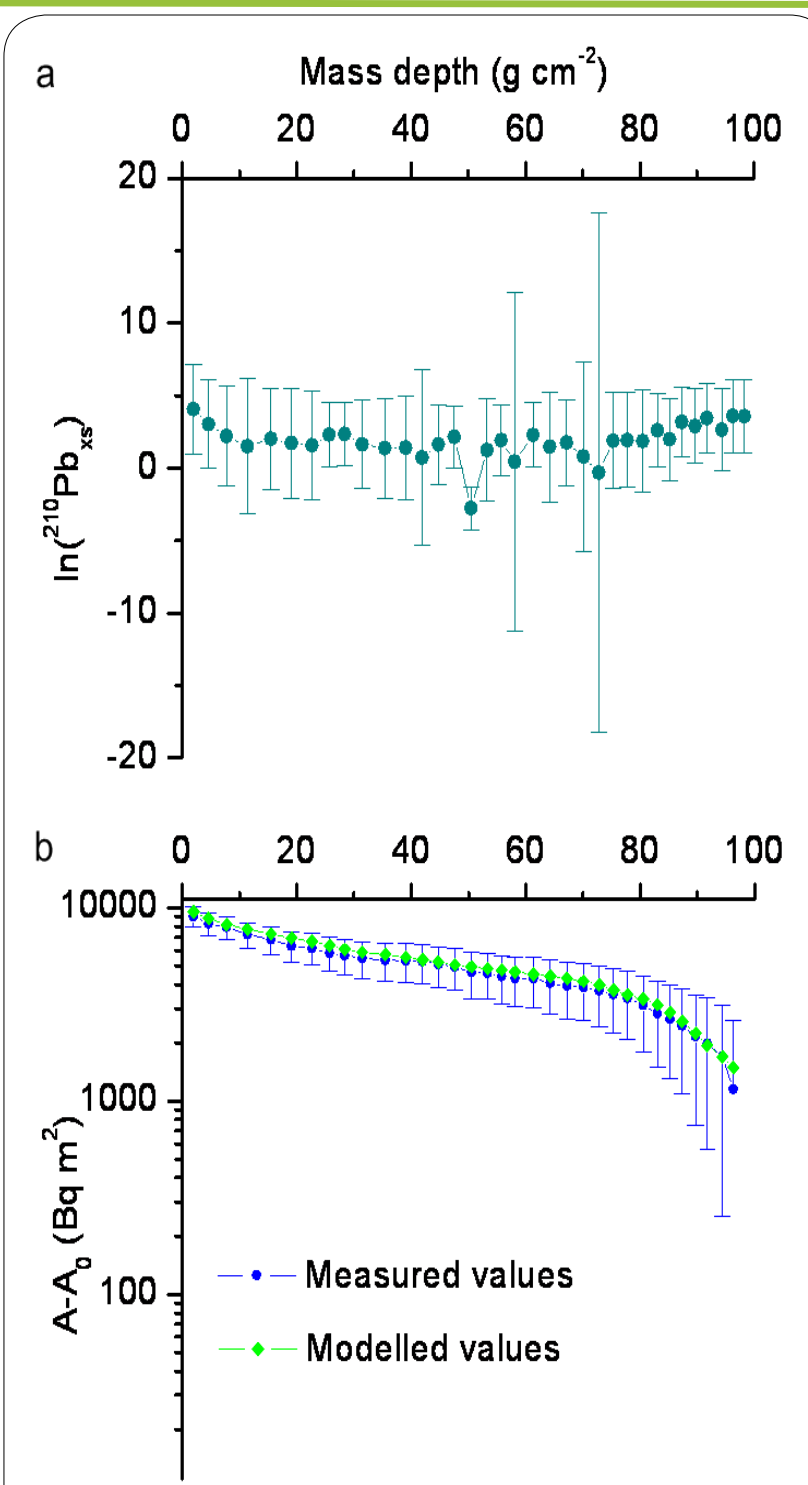

Figure 6: a) Mass depth profile of $210 \mathrm{Pbxs}$ specific activity plotted on a log scale; b) Mass depth profiles of $210 \mathrm{Pbxs}$ inventory. Blue dots correspond to measured values and green diamonds to the modelled values according to the CRS-MV model.

Another application of Itrax data is the study of variations in the organic matter content. This is valuable information to take into account because they can condition the adsorption of toxic metals as well as the distribution and activity of radionuclides in the sediments [44]. The incoherent and coherent scattering (inc/coh) and the $\mathrm{Br} / \mathrm{Cl}$ profiles provided by the Itrax constitute a fast option to study these variations [23,45]. According to Rodríguez-Germade et al. [26], the inc/coh ratio works better when the organic matter comes from a mixture of terrestrial and marine sources, while the $\mathrm{Br} / \mathrm{Cl}$ ratio is only valid when the organic matter is mostly marine. In this case, we have used the inc/coh ratio because the organic matter of the sediments of the study area results from a mixture of both sources [43].The inc/ coh profile of the SS10T03 core (Figure 5) showed a p.a. average of $2.2 \pm 0.3$ in the upper part with a reduction at $12 \mathrm{~cm}(1.5 \pm 0.1)$ and a marked increase from $34 \mathrm{~cm}$ to the bottom $(3.4 \pm 0.4)$. The inc/coh minimum at $12 \mathrm{~cm}$ matches with the $\mathrm{Pb}$ maximum and both profiles are almost mirror images. This coincidence is due to the scattering 
Citation: Álvarez-Iglesias P, Rodríguez-Germade I, Rubio B, Rey D, Quintana B (2016) Monitoring and Evolution of Highly Lead Polluted Coastal Environments: A Case Study in San Simón Bay (NW Spain). Int J Earth Environ Sci 1: 112. doi: http://dx.doi.org/10.15344/ijees/2016/112

Page 8 of 11

behaviour because incoherent scattering is more common in lighter elements with low atomic numbers, while coherent scattering prevails in heavier elements with high atomic numbers [46]. For that reason, the extremely high $\mathrm{Pb}$ concentration at $12 \mathrm{~cm}$ (around $4.0 \%$ according to the extrapolation of the Itrax data from the SS10T01 core) results in a marked increase of the coherent scattering and a consequent inc/ coh reduction. However, $\mathrm{Pb}$ concentration is significantly lower at 34 $\mathrm{cm}$ showing a less influence on the inc/coh ratio. In this case, the inc/ coh increase indicates a higher organic matter content in the bottom of the core which affected to the radionuclides activity as it was shown in section 4.2 (Figure 5).

\section{Chronological framework and sedimentation rates}

The sedimentation rates obtained by ${ }^{210} \mathrm{~Pb}_{\mathrm{xs}}$ and ${ }^{137} \mathrm{Cs}$ dating are comparable: around $7.6 \pm 4.0 \mathrm{~mm} \mathrm{yr}^{-1}$ (for the whole core) and around $5.3 \mathrm{~mm} \mathrm{yr}^{-1}$ (for the upper $25 \mathrm{~cm}$ ) respectively; and similar to those indicated in previous studies (5.5-6.0 $\mathrm{mm} \mathrm{yr}^{-1}$, [8-9]). If the ${ }^{137} \mathrm{Cs}$ specific activity profile of SS10T03 core is compared (Figure 7a) to those of the cores previously studied (SSMPA and C2, collected in 2003 and 1999 respectively) in the same area of San Simón Bay [8-9], the profiles are very similar. In the SSMPA core it is observed an upwards increase of the activity in the first $20 \mathrm{~cm}$, with a slight diminution of this trend between 6 and $2 \mathrm{~cm}$. Something similar is also observed in the first $16 \mathrm{~cm}$ of the $\mathrm{C} 2$ core, with that slight diminution detected in the surficial samples; while this is observed between 11 and $6 \mathrm{~cm}$ for the SS10T03 core. Then, it is detected a displacement of this interval of about 4-5 cm (considering comparison to SSMPA core) or $9 \mathrm{~cm}$ (considering $\mathrm{C} 2$ core), indicating sedimentation rates of 5.7-7.1 mm $\mathrm{yr}^{-1}$ or $8.2 \mathrm{~mm} \mathrm{yr}^{-1}$, respectively, for the most recent sediments (rates very similar to those obtained by the CRS-MV method considering only the upper $13 \mathrm{~cm}: 7.2 \pm 2.5 \mathrm{~mm} \mathrm{yr}^{-1}$ ).

Another option to estimate sedimentation rates is to consider the $\mathrm{Pb}$ inputs to the Bay as a time marker by comparison of $\mathrm{Pb}$ depthprofiles for cores collected at different times. In this case, the proved reliability of Itrax data and the similarities observed in the $\mathrm{Pb}$ profiles of the SS10 cores (section 5.1) allowed the use of the SS10T03 Pb profile (Itrax data) for these estimations. Figure $7 \mathrm{~b}$ showed a marked displacement of the $\mathrm{Pb}$ subsurficial maximum of about 6 or $7 \mathrm{~cm}$ when comparing $\mathrm{Pb}$ profiles for the cores SS10T03, SSMPA and C2, obtaining sedimentation rates of $5.5 \mathrm{~mm} \mathrm{yr}^{-1}$ and $6.4 \mathrm{~mm} \mathrm{yr}^{-1}$. This is in concordance with the temporal framework obtained by the application of the CRS-MV method in the SS10T03 core. Then, the sedimentary record of this core would span about 60 years.

In spite of these sedimentation rates variations, the $\mathrm{Pb}$ profile of the SSMPA core shows clearly the beginning of the Pontesa ceramic factory activity around 1972 with $\mathrm{Pb}$ contents close to or similar to background levels before this year (depths higher than $25 \mathrm{~cm}$ ). This industrial activity resulted in a significant $\mathrm{Pb}$ increase from $18 \mathrm{~cm}$ depth (in core SS10T03) towards the surface reaching a maximum waste discharge at the beginning of the 1990s. Since then, $\mathrm{Pb}$ contents decreases upwards and, despite the Pontesa factory closure in 2001, very high $\mathrm{Pb}$ concentrations still remain in 2010 .

\section{Lead geochemistry and inputs}

Pollution levels in San Simón Bay were previously calculated in former studies [4,7] because this zone is vulnerable to pollutants accumulation due to the physiography and hydrodynamics of this sedimentary environment. Moreover, a special attention has been dully paid to the effects of the old ceramic factory, identified as the main source of $\mathrm{Pb}[4,10-11]$ and subsequently, the highest pollution problem in this area. Total $\mathrm{Pb}$ contents in the SS10T01 core were extremely high (1.72-6.67\%). The whole core is polluted with Enrichment Factors [47] between 560 and 1,250 (where EF $=([\mathrm{Pb}] /$ $[\mathrm{Al}] /([\mathrm{Pb}] \mathrm{BL} /[\mathrm{Al}] \mathrm{BL})$, being $\mathrm{BL}=$ background level and considering established $\mathrm{BL}$ for the study area of $54 \mu \mathrm{g} \mathrm{g}^{-1}$ for $\mathrm{Pb}$ and $9.91 \%$ for $\mathrm{Al}$ for granitic sources [43]).

About $18 \%$ of $\mathrm{Pb}$ appeared in the bioavailable fraction, whereas more than a half was detected in the recoverable fraction. This means that high quantities of $\mathrm{Pb}$ are adsorbed onto sedimentary particles, forming insoluble salts and organic complexes, which are environmentally available. In comparison to other cores collected in the same area in $1999[6,48]$ the percentages of $\mathrm{Pb}$ in the recoverable and the residual fractions are similar but in the opposite way $(56 \%$ residual and $44 \%$ recoverable). This small difference could be due to a higher proximity to the ceramic factory of the SS10T01 core, since samples collected in the waste channel of the factory in 1999 [4] also showed higher percentages of $\mathrm{Pb}$ in the recoverable fraction. Moreover $\mathrm{Pb}$ stable isotope ratios showed values lower than those typical of natural sediments of the study area [10] and close to those characteristics of the ceramic factory samples [10], (see also Table 2). The observed isotopic ratios are similar to those of the upper centimetres of the core SSPMA, an interval affected by the ceramic waste inputs after the establishment of the ceramic factory, which started at the beginning of the 1970s [10].

When calculating the correlations among the different isotopic ratios for each fraction it is observed high relationships $\left(\mathrm{r}^{2}\right.$ between 0.8463 and 0.9991 ). This is consequence of a mixture of natural and anthropogenic $\mathrm{Pb}$ sources to the sediments. In order to determine the total anthropogenic component (TAC) of the different $\mathrm{Pb}$ stable isotope ratios, the mixture model proposed by Ferrand et al. [35] was applied. Results obtained for the different sediment fractions are shown in Table 2. It is observed that the isotopic ratios are close to the characteristic ratios of gypsum from the ceramic factory, confirming, as previously indicated [10], that the main $\mathrm{Pb}$ source to the Bay in recent years has been the ceramic factory. Furthermore, in the case of the studied sediments, the anthropogenic $\mathrm{Pb}$ inputs $\left(\mathrm{Pb}_{\text {anthr }}\right)$ calculated by subtraction of the natural $\mathrm{Pb}$ input for each sample (estimated considering $\mathrm{Al}$ concentrations as a grain-size proxy, that is, based on $\mathrm{Pb} / \mathrm{Al}$ ratios) indicate that the $\mathrm{Pb}_{\text {anthr }}$ represents $99.8-99.9 \%$ of total $\mathrm{Pb}$ in the samples. Then, in this case, when applying a binary mixing model [35-36] to estimate the anthropogenic lead isotope ratios for each depth they are almost the same as the total sample isotopic ratios (Table 2). Furthermore, they are very close to those anthropogenic lead ratios estimated for the upper centimetres of the SSMPA core (Table 3;[10]).

The application of a three source model [37-38] to the isotopic ratios determined for the total fraction to apportion the different $\mathrm{Pb}$ anthropogenic sources, considering the isotopic signatures of the different sources (ceramic factory, petrol and coal) selected by ÁlvarezIglesias et al. [10] after a literature revision on isotopic signatures of Spain and another western European countries (Table 3), confirmed the ceramic factory as the main $\mathrm{Pb}$ anthropogenic input to the Bay (96 $\pm 6 \%$ of the $\mathrm{Pb}$ inputs), whereas the contribution of petrol-related inputs was very small $(4 \pm 6 \%)$, and that of coal-related inputs, null or almost negligible. 
Citation: Álvarez-Iglesias P, Rodríguez-Germade I, Rubio B, Rey D, Quintana B (2016) Monitoring and Evolution of Highly Lead Polluted Coastal Environments: A Case Study in San Simón Bay (NW Spain). Int J Earth Environ Sci 1: 112. doi: http://dx.doi.org/10.15344/ijees/2016/112

Page 9 of 11

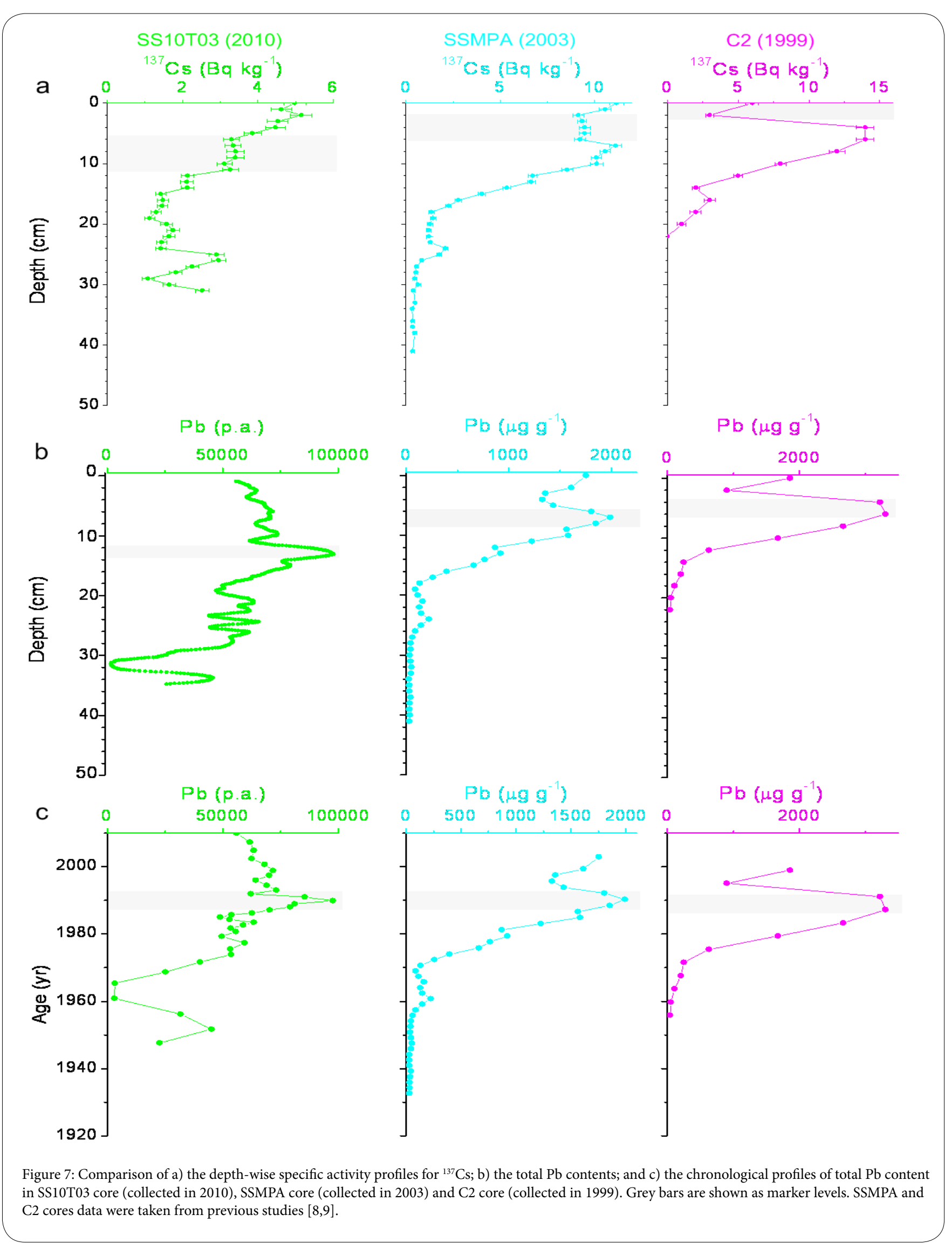


Citation: Álvarez-Iglesias P, Rodríguez-Germade I, Rubio B, Rey D, Quintana B (2016) Monitoring and Evolution of Highly Lead Polluted Coastal Environments: A Case Study in San Simón Bay (NW Spain). Int J Earth Environ Sci 1: 112. doi: http://dx.doi.org/10.15344/ijees/2016/112

Page 10 of 11

\begin{tabular}{|l|l|l|l|l|l|}
\hline Sedimentary core or $\mathrm{Pb}$ source & ${ }^{206 \mathrm{P}} \mathrm{b} /{ }^{207} \mathrm{~Pb}$ & ${ }^{208} \mathrm{~Pb} /{ }^{207} \mathrm{~Pb}$ & ${ }^{206} \mathrm{~Pb} /{ }^{204} \mathrm{~Pb}$ & ${ }^{207} \mathrm{~Pb} /{ }^{204} \mathrm{~Pb}$ & ${ }^{208} \mathrm{~Pb} /{ }^{204} \mathrm{~Pb}$ \\
\hline SS10T01 & 1.1631 & 2.4456 & 18.154 & 15.609 & 38.171 \\
\hline SSMPA & 1.1581 & 2.3867 & 18.091 & 15.622 & 38.195 \\
\hline SSMPA $(17 \mathrm{~cm})$ & 1.1671 & 2.3139 & 18.229 & 15.620 & 38.268 \\
\hline Petrol & 1.10 & $2.37-2.38$ & $17.06-17.23$ & $15.48-15.51$ & $36.75-36.93$ \\
\hline Coal & $1.18-1.19$ & $2.47-2.48$ & 18.6 & 15.69 & $38.55-38.71$ \\
\hline Ceramicfactory (gypsum) & 1.1649 & 2.4524 & 18.171 & 15.599 & 38.256 \\
\hline
\end{tabular}

Table 3: Average $\mathrm{Pb}$ isotopic signature of the anthropogenic inputs considering a binary mixing model for cores SS10T01 (N=10) and SSMPA (N=42 total core, and $\mathrm{N}=18$, upper $17 \mathrm{~cm}$ ) together with typical $\mathrm{Pb}$ isotopic signature of the anthropogenic sources to San Simón Bay (according to Âlvarez Iglesias et al. [10]).

\section{Conclusion}

Even though San Simón Bay is a coastal system with anthropogenic $\mathrm{Pb}$ inputs, ${ }^{210} \mathrm{~Pb}$ and ${ }^{137} \mathrm{Cs}$ dating, together with a detailed geochemical study (including high-resolution Itrax data) allowed establishing sedimentation rates and determining the historical trend of metal inputs in the sediments. Moreover, sedimentations rates estimated from Itrax profiles matched with those estimated from ${ }^{210} \mathrm{~Pb}$ and ${ }^{137} \mathrm{Cs}$ dating.

Itrax data are very useful to minimise grain size effects (normalizing with Fe or Ti profiles) and to follow the relative variations of sediments composition (e.g., inc/coh as indicative of organic matter content) that could affect radionuclides activities or metals distribution. Moreover considering pollutant inputs as time markers, Itrax $\mathrm{Pb}$ profiles are valid to calculate sedimentation rates and to monitor spatial and temporal $\mathrm{Pb}$ pollution.

The application of several models on $\mathrm{Pb}$ stable isotopes confirmed that the ceramic factory is the main source of anthropogenic $\mathrm{Pb}$ in San Simón Bay even after its closure around 2001. In fact, extremely high $\mathrm{Pb}$ concentrations in sediments remain in 2010. More than half of this $\mathrm{Pb}$ was detected in the recoverable fraction and it could be released to the water column due to redox changes. Moreover, a $18 \%$ of the total $\mathrm{Pb}$ is in the bioavailable fraction, resulting in an alarming pollution problem taking into account the high $\mathrm{Pb}$ concentrations. These considerations suggest the need of environmental projects to recover these kind of fragile ecosystems, where XRF core scanners could represent powerful, quick and reliable tools for environmental coastal management.

\section{Acknowledgement}

This work was supported by the Spanish Ministry of Science and Innovation through projects IPT-310000-2010-17 (INNODRAVAL) and GCL2010-16688 and by the Xunta de Galicia through project 10MMA312022PR. I. Rodríguez-Germade was funded by a FPU scholarship from the Spanish Ministry of Education .P.A.-I. thanks the support from the Xunta de Galicia (Spain) through a postdoctoral contract and a short stay fellowship under the Ângeles Alvariño programme.

\section{References}

1. Plater AJ, Appleby PG (2004) Tidal sedimentation in the Tees estuary during the 20th century: radionuclide and magnetic evidence of pollution and sedimentary response. Estuar Coast and Shelf Sci 60: 179-192.
2. Hwang H, Green PG, Young TM (2009) Historical trends of trace metals in a sediment core from a contaminated tidal salt marsh in San Francisco Bay. Environ Geochem and Health 31: 421-430.

3. Zhang R, Zhou L, Zhang F, Ding Y, Gao J, et al. (2013) Heavy metal pollution and assessment in the tidal flat sediments of Haizhou Bay, China. Mar Pollut Bull 74: 403-412.

4. Álvarez-Iglesias P, Rubio B, Vilas F (2003) Pollution in intertidal sediments of San Simón Bay (Inner Ria de Vigo, NW of Spain): total heavy metal concentrations and speciation. Mar Pollut Bull46 4: 491-503.

5. Belzunce-Segarra MJ, Bacon JR, Prego R, Wilson MJ (1997) Chemical forms of heavy metals in surface sediments of the San Simon inlet, Ria de Vigo, Galicia. J of Environ Sci and Health. Part A Environ Sci Eng Toxic 32: 1271-1292.

6. Álvarez-Iglesias P, Rubio B, Vilas F (2000) Especiación de plomo en sedimentos y niveles de concentración en organismos de la zona intermareal de la Ensenada de San Simón (Ría de Vigo, NO España). Thalassas 16: 79-94.

7. Álvarez-Iglesias P, Rubio B, Pérez-ArluceaM (2006) Reliability of subtidal sediments as "geochemical recorders" of pollution input: San Simón Bay (Ría de Vigo, NW Spain). Estuar Coast and Shelf Sci 70: 507-521.

8. Álvarez-lglesias P, Quintana B, Rubio B, Pérez-Arlucea M (2007) Sedimentation rates and trace metal input history in intertidal sediments from San Simón Bay (Ría de Vigo, NW Spain) derived from ${ }^{210} \mathrm{~Pb}$ and ${ }^{137} \mathrm{Cs}$ chronology. J Environ Radioacti 98: 229-250.

9. Álvarez-lglesias P, Rubio B (2009a) Geochemistry of marine sediments from inner Ría de Vigo (NW of Spain). J Radioanal and Nuclear Chem 281: 247-251.

10. Álvarez-Iglesias P, Rubio B, Millos J (2012) Isotopic identification of natural vs. anthropogenic lead sources in marine sediments from the inner Ría de Vigo (NW Spain). Sci Tot Environ 437: 22-35.

11. PregoR., Cobelo-García A (2002) El ciclo biogeoquímico de los metales pesados en la Ría de Vigo: Estado actual de su conocimiento. Revista Real Academia Galega de Ciencias 21: 67-86.

12. Evans G, Howarth RJ, Nombela MA (2003) Metals in the sediments of Ensenada de San Simón (inner Ría de Vigo), Galicia, NW Spain. App Geochem 18: 973-996.

13. Howarth RJ, Evans G, Croudace IW, Cundy AB (2005) Sources and timing of anthropogenic pollution in the Ensenada de San Simón (inner Ría de Vigo), Galicia, NW Spain:an application of mixture-modelling and nonlinear optimization to recent sedimentation. Sci Tot Environ 340: 149-176.

14. Quintana B, Álvarez-Iglesias P, Santamaría R, Rubio B, Pérez-Arlucea $\mathrm{M}(2006)$ Low-level gamma spectrometry for pollution assessment in San Simón Bay (Vigo, Spain). J Physics: Conf Ser 41: 400-407.

15. Díaz-Asencio $\mathrm{M}$, Alonso-Hernández $\mathrm{CM}$, Bolanos-Álvarez $\mathrm{Y}$, GómezBatista M, Pinto V, et al. (2009) One century sedimentary record of $\mathrm{Hg}$ and $\mathrm{Pb}$ pollution in the Sagua estuary (Cuba) derived from ${ }^{210} \mathrm{~Pb}$ and ${ }^{137} \mathrm{Cs}$ chronology. Mar Pollut Bull 59: 108-115.

16. Lepland A, Andersen TJ, Lepland A, Arp HPH, Alve E, et al. (2010) Sedimentation and chronology of heavy metal pollution in Oslo harbor, Norway. Mar Pollut Bull 60: 1512-1522. 
Citation: Álvarez-Iglesias P, Rodríguez-Germade I, Rubio B, Rey D, Quintana B (2016) Monitoring and Evolution of Highly Lead Polluted Coastal Environments: A Case Study in San Simón Bay (NW Spain). Int J Earth Environ Sci 1: 112. doi: http://dx.doi.org/10.15344/ijees/2016/112

Page 11 of 11

17. Nielsen SP (1995) A box model for North-East Atlantic coastal waters compared with radioactive tracers. J Mar Syst 6: 545-560

18. Andersen TJ, Mikkelsen OA, Møller AL(2000) Deposition and mixing depths on some European intertidal mudfats based on ${ }^{210} \mathrm{~Pb}$ and ${ }^{137} \mathrm{Cs}$ activities. Cont Shelf Res 20: 1569-1591.

19. Robbins JA (1978) Geochemical and geophysical applications of radioactive lead. In: The Biogeochemistry of Lead in the Environment. Nriagu J.O. (Ed.), Elsevier, Amsterdam 1978, 285-393.

20. Appleby PG, Oldfield F, Thompson R, Hottunen $P(1979){ }^{210} \mathrm{~Pb}$ dating of annually laminated lake sediments from Finland. Nature 280: 53-55.

21. Appleby PG, Oldfield F (1983) The assessment of 210Pb data from sites with varying sediment accumulation rates. Hydrobiol 103: 29-35.

22. Appleby PG, Oldfield F (1992) Application of lead-210 to sedimentation studies. In: Uranium-series Disequilibrium Applications to Earth, Marine and Environmental Sciences. Ivanovich, M., Harmon, R.S. (Eds.), Clarendon Press, Oxford 731-778.

23. Croudacel W, Rindby A, Rothwell RG (2006) ITRAX: description and evaluation of a new multi-function X-ray core scanner. In: Rothwell, R.G. (Ed.) New Techniques in Sediment Core Analysis. Geol Soc London Spec Publ 51-63.

24. Croudace IW, Warwick PE, Morris JE (2012) Evidence for the Preservation of Technogenic Tritiated Organic Compounds in an Estuarine Sedimentary Environment. Environ Sci Technol 46: 5704-5712.

25. Martins VA, Dias JA, Bernardes C, Rubio B, Bernabeu A, et al. (2013) The ITRAX core scanner, a useful tool to distinguish Anthropic vs. Climatic influences in lagoon of Aveiro (N Portugal). J Coast Res 65: 70-75.

26. Rodríguez-Germade I, Rubio B, Rey D (2014) XRF scanners as a quick screening tool for detecting toxic pollutant elements in sediments from Marín harbour in the Ría de Pontevedra (NW Spain). Mar Pollut Bull 86 458-467.

27. Rodríguez-Germade I, Rubio B, Rey D, Borrego J (2015) Detection and monitoring of REEs and related trace elements with an ItraxTM Core Scanner in the Ría de Huelva (SW Spain). Water, Air and Soil Pollut 226 : 137

28. Walraven N, van Os BJH, Klaver GTh, Middelburg JJ, Davies JR (2014) Reconstruction of historical atmospheric $\mathrm{Pb}$ using Dutch urban lake sediments: A Pb isotope study. Sci Tot Environ 484: 185-195.

29. Véron A, Flament P, Bertho ML, Alleman L, Flegal R, Hamelin B (1999) Isotopic evidence of pollutant lead sources in Northwestern France. Atmosph Environ 33: 3377-3388.

30. Pérez-Arlucea M, Álvarez-Iglesias P, Rubio B (2007) Holocene Evolution of Estuarine and Tidal-flat Sediments in San Simón Bay, Galicia, NW Spain. J Coast Res 50: 163-167.

31. Pérez-Arlucea M, Filgueira M, Freijido M, Méndez G (2000) Parámetros morfométricos e hidrológicos de las cuencas de drenaje y ríos tributarios a la ría de Vigo. Estimación de las variaciones anuales en la cargas en suspensión y en disolución. J Iberian Geol 26: 171-187.

32. Nombela M A, VilasF, EvansG (1995) Sedimentation in the mesotidal Rias Bajas of Galicia (nort-western Spain): Ensenada de San Simón, Inner Ria de Vigo. Spec Publ Int Assoc Sedimentol 24: 133-149.

33. Álvarez-Salgado XA, Gago J, Míguez BM, Gilcoto M, Pérez FF (2000) Surface waters of the NW Iberian Margin: upwelling on the shelf versus outwelling of upwelled waters from the Rías Baixas. Estuar Coast Shelf Sci 51: 821-837.

34. Catalogue of National Water Research Institute (2006) Certified Reference Materials \& Quality Assurance Services. Canada Centre for Inland Waters National Laboratory for Environmental Testing Burlington, Ontario, Canada, v 5.7 .

35. Ferrand JL, Hamelin B, Monaco A (1999) Isotopic tracing of anthropogenic $\mathrm{Pb}$ inventories and sedimentary fluxes in the Gulf of Lions (NW Mediterranean sea). Cont Shelf Res 19: 23-47.

36. Eades LJ, Farmer JG, MacKenzie AB, Kirika A, Bailey-Watts AE (2002) Stable lead isotopic characterisation of the historical record of environmental lead contamination in dated freshwater lake sediment cores from northern and central Scotland. Sci Tot Environ 292: 55-67.
37. Chiaradia M, Chenhall BE, Depers AM, Gulson BL, Jones BG (1997) Identification of historical lead sources in roff dusts and recent lake sediments from an industrialized area: indications from lead isotopes. Sci Tot Environ 205: 107-128.

38. Cheng $\mathrm{H}, \mathrm{Hu} \mathrm{Y}(2010)$ Lead $(\mathrm{Pb})$ isotopic fingerprinting and its applications in lead pollution studies in China: a review. Environ Pollut 158: 1134-1146.

39. Álvarez-Iglesias P, Andrade A, Quintana B, Rubio B, Rey D, Fedi M, Caforio L, Taccetti F (2011a) Cronología de la contaminación por elementos traza en sedimentos de la Ría de Muros (Noroeste de la Península Ibérica). Libro de resúmenes del XVII Encontro Galego-Portugués de Química, 83, Pontevedra (España)

40. Álvarez-Iglesias P, Rubio B, Vilas F, Quintana B, Millos J (2011b) Avances en la determinación de la cronología y procedencia de sedimentos mediante isótopos. In: Métodos y Técnicas en Investigación Marina. Sección III Oceanografía. Capítulo XXXI. García Estévez, J.M., Olabarría, C., Pérez, S., Rolán-Álvarez, E., Rosón, G., (Coords.). Editorial Tecnos (Grupo ANAYA, S.A.), Madrid. 371-381.

41. Schell WR, Tobin MJ (1994) ${ }^{210} \mathrm{~Pb}$ dating using the CRS-MV model with historical data to test and evaluate accuracy. in: García-León, M., GarcíaTenorio, R. (Eds.), Proceedings of the Third International Summer School: Low Level Measurements of Radioactivity in the Environment, Techniques and Applications. World Scientific Publishing Co., 355-368.

42. Oldfield F, Appleby PG (1984) Empirical testing of ${ }^{210} \mathrm{~Pb}$-dating models for lake sediments. In: Haworth, E.Y., Lund, J.W.G. (Eds.), Lake Sediments and Environmental History. Leicester University, 93-124.

43. Álvarez-Iglesias P, RubioB (2012) Early diagenesis of organic-matterrich sediments in a ría environment: Organic matter sources, pyrites morphology and limitation of pyritization at depth. Estuar Coast Shelf Sci 100: 113-123.

44. Jurina I, Ivanić M, Troskot-Čorbić T, Barišić D, Vdović N, et al. (2013) Activity concentrations and distribution of radionuclides in surface and core sediments of the Neretva Channel (Adriatic Sea, Croatia). Geologia Croatica 66: 143-150.

45. Rolland N, Larocque I, Francus P, Pienitz R, Laperrière L (2008) Holocene climate inferred from biological (Diptera: Chironomidae) analyses in a Southampton Island (Nunavut, Canada) lake. The Holocene 18: 229-241.

46. Clark GL (1932) The absorption and scattering of $x$-rays. In: Richtmyer, F.K. (Ed.), Applied X-rays. Mc-Graw-Hill, New York and London, 97.

47. Zoller WH, Gladney ES, Gordon GE, Bors JJ (1974) Emissions of trace elements from coal fired power plants. In: Hemphill, D.D. (Ed), Trace Substances in Environmental Health, vol. 8. Rolla, University of Missouri, Colombia, 167-172.

48. Álvarez-Iglesias P, Rubio B (2009b) Redox status and heavy metal risk in intertidal sediments in NW Spain as inferred from the degrees of pyritization of iron and trace elements. Mar Pollut Bull 58: 542-551.

49. Rodríguez-Germade I, Rubio B, Rey D, Vilas F, Martins V, et al. (2013) Evaluación de técnicas de procesado de datos geoquímicos en sedimentos marinos analizados con un Itrax Core Scanner. Geogaceta 53: 85-88. 